\title{
Managing the remains of fetuses and abandoned infants: A call to urgently review South African law and medicolegal practice
}

\author{
L du Toit-Prinsloo, ${ }^{1}$ MB ChB, DipForMed (SA) Path, FCForPath (SA), MMed (Path) (Forens); C Pickles, ${ }^{2}$ LLB, LLM, LLD; \\ G Saayman, ${ }^{1} \mathrm{MB} \mathrm{ChB}, \mathrm{MMed}$ (Med Forens), FCForPath (SA) \\ ${ }^{1}$ Department of Forensic Medicine, School of Medicine, Faculty of Health Sciences, University of Pretoria, South Africa \\ ${ }^{2}$ South African Institute for Advanced Constitutional, Public, Human Rights and International Law, University of Johannesburg, South Africa
}

Corresponding author: $L$ du Toit-Prinsloo (lorraine.dutoit@up.ac.za)

This article reviews South African (SA) law and its impact on the medicolegal management of fetal remains emanating from elective and therapeutic termination of pregnancies, stillbirths and miscarriages and the remains of abandoned or exposed infants. It was found that remains are treated differently, some constituting medical waste while others have sufficient status in law to allow for burial. This approach results in some women or couples being denied a choice with regard to disposal via culturally relevant practices, and is insensitive to the fact that all remains ultimately constitute human remains. The article argues that SA law is in urgent need of reform, and turns to foreign law and forensic practice to shed light on possible alternative approaches that could assist with developing the SA position and thereby improve the practical management of fetal and infant remains in SA.

S Afr Med J 2016;106(6):578-581. DOI:10.7196/SAMJ.2016.v106i6.10598

Current South African (SA) legislation and common law principles leave many questions pertaining to the management of fetuses and infants in clinical and forensic pathology practice. The application of different legislation to different areas of medical practice results in different status being assigned to fetal and/or infant remains. Some women or couples are denied a choice with regard to disposal of fetal remains via culturally relevant practices such as burial or cremation. Current legislation also compromises effective investigation into problematic areas such as the illegal disposal of fetal remains or infants by members of the public.

This article considers the SA law relevant to fetal and infant remains and reveals a number of inconsistencies and concerns. It then turns to foreign law and forensic practice to inform possible changes to the SA position with the aim of improving the practical management of fetal and infant remains in SA.

\section{Legislation pertaining to the management of fetall remains in SA}

In $\mathrm{SA}$, the fetus is not vested with any constitutional rights and is primarily viewed as being part of the body of a pregnant woman. ${ }^{[1]}$ This position is accepted by the authors. However, the authors assert that legislative provisions relating to the management of fetal and infant remains should be clear and consistent, providing appropriate guidance for all reasonably foreseeable outcomes. Legislative provisions should specifically also cater for the subjective need for respectful and sensitive management of all forms of human remains, including those of fetuses and abandoned infants. It is not possible to accommodate this stance in practice because of the approach currently adopted by the law.

Choice on Termination of Pregnancy Act 92 of $1996^{[2]}$

The Choice on Termination of Pregnancy Act ${ }^{[2]}$ (Choice Act) is primarily concerned with ensuring access to safe termination of pregnancy (TOP) services and the regulation of the provision of these services.

Section 1 of the Act defines a TOP as 'the separation and expulsion, by medical or surgical means, of the contents of the uterus of a pregnant woman'. The term 'contents' is not defined, and it can be taken to broadly include fetal matter, placenta, and any other tissue and blood material removed from a woman's uterus. Once removed, section 3(1)(i) of the Choice Act requires that the products of conception must be managed, but aside from requiring facilities to have access to safe waste disposal infrastructure' the Act and regulations do not deal with this issue. The Act does not define 'waste' or 'disposal'.

According to regulation 2(xxxv) of the Gauteng Health Care Waste Management Regulations, ${ }^{[3]}$ in terms of the Environment Conservation Act 73 of $1989,{ }^{[4]}$ the definition of 'pathological waste' includes 'human fetuses'. Consequently, all fetal remains derived from TOP are afforded the status of medical waste and are disposed of in such a manner as to not pose a risk to public health.

This position presumes that all fetal remains stemming from TOP procedures are equally of no value, and all are accorded the status of pathological waste without any meaningful consideration of parties involved (including the mother/father). The presumption stands regardless of whether the TOP is an elective or therapeutic procedure, or whether the pregnancy is viable or non-viable. This hampers the development of alternative methods of disposal and denies choice with regard to disposal methods. The fact is that even pregnancies that are deliberately terminated can be considered a loss by women or couples. ${ }^{[5]}$ The current approach is devoid of respect and sensitivity.

Births and Deaths Registration Act 51 of $1992^{[6]}$

Miscarriages and stillbirths are both serious complications of pregnancy that result in loss of the pregnancy and produce fetal remains. The dividing line between miscarriage and stillbirth pivots on the viability or ability to survive of a fetus. Dorland's Medical Dictionary defines a miscarriage as 'a popular term for spontaneous 
abortion', spontaneous abortion as 'abortion occurring naturally; popularly known as miscarriage', and stillbirth as 'the delivery of a dead child. ${ }^{[7-9]}$ Many countries have legislation pertaining to the registration of stillbirths, with a specified gestational age attached to the definition. However, the conceptualisation of fetal viability in law is problematic, since the term generally fails to capture the essence of what viability means in a clinical setting. This failure relates to the fact that the law primarily relies on gestational age as an indicator of the ability to survive, while research indicates that viability is context sensitive, making the consideration of gestational age inconclusive when considered in isolation. ${ }^{[10]}$

In SA, the Births and Deaths Registration Act ${ }^{[6]}$ regulates the registration of births and deaths. Section 1 of the Act also defines 'burial' as 'burial in the earth or the cremation or any other mode of disposal of a corpse'. This legislation is also applicable to the management of fetal remains emanating from a stillbirth or miscarriage, as it specifies what remains qualify for registration of 'deaths' and later burial, but uses gestational age alone as an indicator of whether one is dealing with a stillbirth or miscarriage.

The provisions relevant to the registration of deaths relate to 'persons' and those who are 'stillborn', indicating that the option of burial is limited to a particular 'person' or 'stillborn child'. 'Person' is not defined in the Act, but in SA, the legal concept of person does not include the unborn. ${ }^{[1]}$ Furthermore, section 1 of the Act narrowly defines 'stillbirth' or 'stillborn' as involving a 'child' that 'has had at least 26 weeks of intra-uterine existence but showed no sign of life after birth. Consequently, not all fetal remains originating from pregnancy complications can be buried. Should a pregnancy of less than 26 weeks' gestation come to an end, the fetal remains will be assigned the status of pathological waste.

This Act ${ }^{[6]}$ treats fetal remains emanating from pregnancy complications differently to remains emanating from TOP, especially TOP at a later gestational age (see the example below). The differentiation in status and resulting implications with regard to disposal methods cannot be justified and are insensitive to the position of individuals who experience these situations.

The differences in legal status assigned to a stillborn fetus in terms of the Choice Act ${ }^{[2]}$ and the Births and Deaths Registration Act ${ }^{[6]}$ can be illustrated by the following example. If a woman is 32 weeks pregnant and a stillborn fetus is born, the parents will be issued with a death notification form in terms of the Births and Deaths Registration $\mathrm{Act}^{[6]}$ and can bury or cremate the fetus. If the same woman is informed that continuation of her 32-week pregnancy will result in a severely abnormal infant, and she decides to terminate the pregnancy in terms of the Choice Act ${ }^{[2]}$ the stillborn fetus has to be treated as pathological waste.

'Viability' is not defined by SA legislation, but in case law. S v. Mshumpa ${ }^{[11]}$ accepted that a fetus is capable of independent survival at 25 weeks' gestation. However, in S v Molefe ${ }^{[12]}$ the court ruled that fetal viability occurred at 28 weeks' gestation for purposes of the crime of concealment of birth. The court came to this conclusion without taking into consideration any expert medical evidence, relying on outdated case law from Zimbabwe and Venda. The distinction imposed by the Births and Deaths Registration Act ${ }^{[6]}$ is not only founded on an ill-established legal premise of viability, but it is used as the basis to determine the status of fetal remains and whether the family has the right to bury those remains.

\section{Medicolegal management of remains emanating from abandoned fetuses or infants}

This part of the article considers the general social disregard of fetal or infant remains more broadly and takes its cue from the poor management of fetal remains in the realms of the criminal justice system. Here, the management of fetal or infant remains involves cases in which they are 'inappropriately' disposed of in places not approved of by current legislation and regulations, such as in public toilets, dumps, dustbins or fields or alongside pathways. ${ }^{[13,14]}$ These remains generally originate from unlawful TOP, concealed births or abandoned infants who have died from exposure.

Section 113 of the General Law Amendment Act 46 of 1935 $5^{[15]}$ criminalises concealment of birth. It provides that a person commits this offence if he or she disposes of a body of a newly born child without a lawful burial order, and does so with the intention of concealing its birth. The offence stands regardless of whether the child was born alive or died before, during or after birth. The Act does not define 'child'. However, S v. Molefe ${ }^{[12]}$ provides that 'child' refers to a fetus that has reached at least 28 weeks' gestation. One will therefore not commit this crime if one's conduct involves a fetus of less than 28 weeks' gestation.

The common-law crime of 'exposing' an infant is the unlawful and intentional exposure and abandonment of a liveborn infant in circumstances that are likely to lead to its death. ${ }^{[16]}$ Prosecutions are rare, and if prosecution is pursued, individuals are usually charged with murder. ${ }^{[16]}$ However, the crime of murder can only be committed against a 'person', i.e. one who is born alive. ${ }^{[1]}$ According to section 239(1) of the Criminal Procedure Act 51 of $1977,,^{[17]}$ breathing is sufficient evidence of live birth for purposes of criminal prosecution.

The discovery of discarded fetal or infant remains clearly requires investigation into a number of issues before a criminal charge can be anticipated. When such fetal material or deceased infants are found, the South African Police Service and the Forensic Pathology Service are contacted and the case is usually investigated under the Inquests Act 58 of 1959. ${ }^{[18]}$ An inquest docket is opened and a medicolegal postmortem examination is conducted to establish gestational age, whether the fetus had lived outside the mother, and the cause of death or stillbirth. ${ }^{[19]}$

Since the crimes of murder or exposure are only applicable to those who are born alive, only viable or sufficiently developed fetuses, who were able to breathe, would constitute the subject of a criminal investigation. However, in respect of all possible criminal offences (concealment of birth, exposure or murder), postmortem examination of remains can be very challenging and even rendered fruitless as a result of decomposition, postmortem trauma or predation. ${ }^{[19,20]}$ A criminal charge may not follow simply because essential forensic evidence could not be objectively established.

This discussion demonstrates that not all abandoned remains receive adequate attention in law, despite the fact that all constitute human remains. The dividing line rests on the notion of viability or ability to survive and sufficient evidence thereof. While criminal law provisions and regulatory frameworks appear to provide reasonably clear directions, their application can therefore be difficult in a practical setting. When the required essential characteristics of the remains cannot be established, no legal consequences ensue and perpetrators are not held accountable. It is not unusual practice for fetal remains (or products of conception) that have undergone medicolegal examination to be disposed of as human waste or incinerated. This implies that the remains are worthless. This conclusion is supported by the fact that not all discovered remains are recorded, and statistics relating to the inappropriate disposal of fetal and infant remains are not readily available. According to Jacobs et al., ${ }^{[21]}$ 'no research was found that specifically investigates the phenomenon of dumping babies and fetuses'.

Discussions on improving criminal/statutory provisions and social support systems cannot be meaningfully engaged in as long as fetal 
and infant remains are deemed pathological waste. The current legal situation results in acts of abandonment remaining invisible and unaddressed. The extent of abandonment, factors facilitating that behaviour and the underlying social reasons are likely to remain unknown. Accordingly, effective regulatory or criminal law provisions will not be developed and meaningful social reform will not take place.

Overall, fetal remains hold an unfortunate position in SA, and the reason for this is not clear. There is no legislation or directives indicating what should be done with fetal remains in practice. The management and method of disposal of the remains should not cause offence, and should advance dignity without compromising the health of the public.

\section{Alternative positions on the management of fetall remains emanating from obstetric practice}

There are approaches that can be adopted to develop a sensitive position regarding the management of fetal remains emanating from obstetric practice. These approaches may be policy based or statute based. Each provides various options for methods of disposal, but also provides decisional space that allows for individualised choices.

The UK adopts a policy-based approach. Methods of disposal of fetal remains were contemplated in the Polkinghorne report. ${ }^{[2]}$ This report proposed that 'on the basis of its potential to develop into a human being, a fetus is entitled to respect, according it a status broadly comparable to that of a living person. ${ }^{\text {'22] }}$ The report questioned the ethical validity of treating pre-viable and viable fetuses differently. Debates concerning the disposal of fetal remains followed, with subsequent formulation of policies and guidelines. One of the issues arising from these debates was the fact that only stillborn infants could be buried, 'stillborn infant' being defined as a fetus of at least 24 weeks' gestation, born without showing any signs of life. ${ }^{[23]}$ Any loss of pregnancy before 24 weeks could not be registered as a death, and no burial of the remains was possible. ${ }^{[4]}$ The Human Tissue Authority's ${ }^{[25]}$ best practice guidelines on the storage and disposal of human organs and tissues now encourages respectful disposal of remains emanating from a pregnancy loss before 24 weeks' gestation: 'pregnancy loss should always be handled sensitively. The needs of the woman or couple should be paramount and disposal policies should reflect this.'[25] Issues surrounding viability, pre-viability, or distinguishing between TOP or various pregnancy complications are therefore no longer relevant for the purposes of sensitive disposal of fetal remains.

Even though the Human Tissue Authority' ${ }^{[25]}$ code of practice is not law, it has been well received. The Cardiff and Vale University Health Board's Policy for the Management of Fetal Remains, Stillbirth and Neonatal Death ${ }^{[26]}$ states that 'women/couples should have choices, regardless of pregnancy gestation and it acknowledges that the death of a baby for some individuals, irrelevant of gestation can be as significant as any bereavement ... staff will ensure that care meets personal, cultural, spiritual, religious and holistic individual requirements. The Royal College of Nursing acknowledges that 'sometimes parents don't recognise their loss at the time, but may return months or even years later to enquire about the disposal arrangements. Therefore it is important to respect the wishes of parents who may not want to be involved, but to ensure that sensitive and dignified disposal is carried out.' ${ }^{[27]}$

Common to all guidelines is the need to dispose of fetal remains sensitively and that disposal should be governed primarily by the wishes of those affected. The guidelines assert that remains should not be categorised as 'medical waste', regardless of how the remains came to be. All directives merely constitute guides, and different institutions or organisations in the healthcare sector each still draft their own guidelines, resulting in inconsistencies between different guidelines and implementation more generally. ${ }^{[28]}$ Furthermore, since guidelines serve as guides only, their authority and weight beyond the clinical setting are limited and they therefore cannot be imposed on those institutions or medical personnel functioning under other legal instruments such as burial and cremation laws. When burial or cremation laws are not aligned with the various health sectors' guidelines, the intention to dispose of fetal remains sensitively may therefore be frustrated. In fact, the authority and weight of guidelines is even questionable in clinical settings, since reports have recently emerged that fetal remains emanating from TOP procedures were being used to 'heat UK hospitals' and that patients were not consulted about what would happen to the remains of their fetuses. ${ }^{[29]}$

The Canadian province of Alberta takes a different approach, adopting a statute-based system that secures respectful and sensitive management of fetal remains. According to the Vital Statistics Act $2007,{ }^{[30]}$ every birth must be registered. The term 'birth' is not limited to specific gestational age; instead, any sign of life after complete expulsion or extraction will suffice. A stillbirth is defined as the complete expulsion or extraction, after at least 20 weeks' gestation or the attainment of at least $500 \mathrm{~g}$, of a fetus that shows no signs of life when delivered. All stillbirths must be registered, but registration takes place as if there has been a birth followed by a death. The death of a person must be registered, and upon receipt of the death registration document, a burial permit must be issued. No person may dispose of a body without such a permit. ${ }^{[30]}$

While there seems to be a gap in respect of burial options for dead pre-viable fetuses, the Alberta Cemeteries Act RSA 2000 CC- $3^{[31]}$ offers support in this regard. The Act authorises the development of regulations that allow for the disposal of fetuses and the bodies of newborn infants who have died, subject in each case to the parents' or guardians' request, and defining a newborn infant for the purposes of the regulations. ${ }^{\left[{ }^{[1]}\right.}$ Regulation 8 of the General Regulation 249/1998 ${ }^{[32]}$ provides that in the case of death of a fetus, the remains need not be disposed of in accordance with the burial requirements specified for a deceased human body, but it specifies that the manner of disposal is subject to the 'parents' or guardian's' request. It further specifies that disposal must not cause public offence. In the case of death of a fetus or newborn infant in a hospital, the hospital may dispose of the remains, but the manner of disposal is subject to the parents' or guardian's request and such disposal may not cause public offence. ${ }^{[32]}$ No distinction is made between remains emanating from elective or therapeutic TOP, or those resulting from pregnancy complications. ${ }^{[32,33]}$

\section{Alternative positions regardling forensic (medicolegall) management of the remains of abandoned fetuses and infants}

A review of practices in the medicolegal management of the remains of abandoned fetuses and infants proved difficult, to the extent that no clear alternatives for managing these cases have been defined.

There are troublesome gaps in the available data. The World Health Organization has indicated that globally an estimated 20 million pregnancies are unsafely terminated each year. ${ }^{[34]}$ While it is accepted that the products of illegally performed early TOPs may not be recognisable and are therefore easily disposed of, there must be laterterm TOPs that do not result in viable births but produce remains that are more difficult to dispose of because of their recognisability and size. From a medicolegal perspective, there are few or no data 
concerning the finding and management of remains emanating from these practices.

Finally, in many countries there is a seemingly endless record of cases of neonaticide and infanticide. Schulte et al. ${ }^{[35]}$ reported that in Germany there were 150 cases of suspected neonaticide from 1993 to 2007, with 45\% remaining unsolved. Herman-Giddens et al. ${ }^{[36]}$ writing on experiences from North Carolina, USA, stated that 'at least 201 per 100000 newborns are known to be killed or left to die per year,' and although they did not review the outcomes of all the cases prosecuted, the sentences varied from none to 25 years' imprisonment. No research is available on the outcomes of such cases in SA.

\section{Conclusions}

SA urgently needs to review the current legislation pertaining to the management of the remains of abandoned fetuses and infants, TOPs and miscarriages. Law reform will allow for improved, sensitive clinical practice.

In the context of clinical management, these changes should strive to allocate the same status to all remains, regardless of how the pregnancies ended. Development in this area should provide people with the opportunity to bury remains appropriately regardless of the gestational age, since it is well known that this assists the grieving process. It should be emphasised that this option should be permissive in nature, rather than an obligation to dispose of a fetus in a culturally relevant way. Where no choice is exercised, disposal should nevertheless be sensitive and respectful.

There appear to be wide variations in reported incidences of abandoned fetuses and infants. Sadly, this is a glaring global concern. Clear frameworks and informative legal guidelines are needed, specifically with regard to medicolegal investigation protocols when handling the remains of abandoned fetuses and infants. Protocols should demonstrate and inculcate respect for fetuses or infants, since these remains are human in nature, and this should stand regardless of whether prosecution is possible or not. This approach will also assist in developing much-needed statistics on the prevalence of illegal TOP and abandonment of infants.

Although all fetal remains are similar, especially in the medicolegal environment, why are they treated so differently?

\footnotetext{
1. Pickles C. Approaches to pregnancy under the law: A relational response to the current South African position and recent academic trends. De Jure 2014;47(1):20-41.

2. Republic of South Africa. Choice on Termination of Pregnancy Act 92 of 1996. Government Gazette, 1996. http://www.gov.za/documents/choice-termination-pregnancy-amendment-act (accessed 7 March 2016).
}

3. Gauteng Health Care Waste Management Regulations. www.validus.co.za/ValidusImages/ HCW13DEC11.pdf (accessed 17 June 2015).

4. Republic of South Africa. Environment Conservation Act 73 of 1989. Government Gazette, 1989. 4. Republic of South Africa. Environment Conservation Act 73 of 1989. Government
http://www.acts.co.za/environment-conservation-act-1989/ (accessed 7 March 2016).

5. Meyers AJ, Lohr PA, Pfeffer N. Disposal of foetal tissue following elective abortion: What women think. J Fam Plann Reprod Health Care 2015;41(2):84-89. DOI:10.1136/jfprhc-2013-100849

6. Republic of South Africa. Births and Deaths Registration Act 51 of 1992. Government Gazette, 1992. www.gov.za/sites/www.gov.za/files/a51_1992.pdf (accessed 7 March 2016).

7. Dorland's Illustrated Medical Dictionary. 31st ed. Philadelphia: Saunders Elsevier, 2007:1186.

8. Dorland's Illustrated Medical Dictionary. 31st ed. Philadelphia: Saunders Elsevier, 2007:5.

9. Dorland's Illustrated Medical Dictionary. 31st ed. Philadelphia: Saunders Elsevier, 2007:1179.

10. Pickles C. Personhood: Proving the significance of the born-alive rule with reference to medical knowledge of foetal viability. Stellenbosch Law Review 2013;24(1):146-164.

11. S v. Mshumpa 20081 SACR 126 (E).

12. S v. Molefe 2012 (2) SACR 574 (GNP) at 578.

13. Jooste B. Cape's dumped baby shame. IOL News, 16 August 2010. http://wwwiol co za/news/southJooste B. Capés dumped baby shame. IOL News, 16 August 2010. http
africa/cape-s-dumped-baby-shame-1.673089 (accessed 15 March 2015).

14. Child K, Hosken G. Born to be dumped. Times Live, 28 May 2012. http://www.timeslive.co.za/ local/2012/05/29/born-to-be-dumped (accessed 15 March 2015).

15. General Law Amendment Act 46 of 1935. http://www.gov.za/documents/general-law-amendmentGeneral Law Amendment Act 46 of 1935. ht
act-14-may-1935-0000 (accessed 6 May 2016).

act-14-may-1935-0000 (accessed 6 May 2016).
6. Snyman CR. Criminal Law. Durban: LexisNexis Butterworths, 2008:428-429.

17. Criminal Procedure Act 51 of 1977. www.justice.gov.za/legislation/acts/1977-051.pdf (accessed 6 May 2016).

18. Inquests Act 58 of 1959. www.justice.gov.za/legislation/acts/1959-58.pdf (accessed 6 May 2016).

19. Knight B, Saukko P. Knight's Forensic Pathology. 3rd ed. New York: Oxford University Press, 2004:439-450.

20. Byard RW. Sudden Death in the Young. 3rd ed. New York: Cambridge University Press, 2010:539-547.

21. Jacobs R, Hornsby N, Marais S. Unwanted pregnancies in Gauteng and Mpumalanga provinces, South Africa: Examining mortality data on dumped aborted fetuses and babies. S Afr Med J 2014;104(12):864-869. DOI:10.7196/SAMJ.8504

22. Polkinghorne J. Review of the Guidance on the Research Use of Fetuses and Fetal Material. London: Her Majesty's Stationary Office, 1989.

23. Births and Deaths Registration Act 1953. http://www.legislation.gov.uk/ukpga/Eliz2/1-2/20/contents (accessed 22 June 2015).

24. Forster R. Disposal of remains of fetus of under 24 weeks' gestation. BMJ 2003;326(7384):338. DOI:10.1136/bmj. $326.7384 .338 / \mathrm{b}$

25. Human Tissue Authority. https://www.hta.gov.uk/policies/hta-guidance-sensitive-handlingpregnancy-remains (accessed 6 May 2016)

26. Cardiff and Vale University Health Board. Policy for Management of Fetal Remains, Stillbirth and Neonatal Death. 2013. http://www.cardiffandvaleuhb.wales.nhs.uk/opendoc/238496 (accessed 26 August 2015).

27. Royal College of Nursing. RCN Gynaecology Nursing Forum Working Group. Sensitive Disposal of all Foetal Remains: Guidance for Nurses and Midwives. London: Royal College of Nursing, 2007. https:// www2.rcn.org.uk/_data/assets/pdf_file/0020/78500/001248.pdf (accessed 6 May 2016).

28. Cameron M, Penney G. Are national recommendations regarding examination and disposal of products of miscarriage being followed? A need for revised guidelines? Hum Reprod 2005;20(2):531 535. DOI:10.1093/humrep/deh617

29. Knapton S. Aborted babies incinerated to heat UK hospitals. The Telegraph, 24 March 2014. http:// www.telegraph.co.uk/news/health/news/10717566/Aborted-babies-incinerated-to-heat-UKhospitals.html (accessed 11 February 2015)

30. Vital Statistics Act 2007. www.qp.alberta.ca/documents/Acts/V04P1.pdf (accessed 6 May 2016).

30. Vital Statistics Act 2007. Www.qp.alberta.ca/documents/Acts/V04P1.pdf (accessed 6 May 2016).
31. Province of Alberta. Alberta Cemeteries Act RSA 2000 CC-3. www.qp.alberta.ca/documents/Acts/ . Province of Alberta. Alberta Cemeterien (accessed 26 August 2015).
C03.pdf

32. Province of Alberta. General Regulation 249/1998. www.qp.alberta.ca/documents/Regs/1998_249.pdf (accessed 17 June 2015).

33. Alberta Health Services. Caring for the remains of your miscarriage. http://www.albertahealthservices. ca/services/Page3814.aspx (accessed 15 March 2015).

34. World Health Organization. Unsafe Abortion: Global and Regional Estimates of the Incidence of Unsafe Abortion and Associated Mortality in 2008. 6th ed. Geneva: WHO, 2008.

35. Schulte B, Rothschild MA, Vennemann M, Banaschak S. Examination of (suspected) neonaticides in Germany: A critical report on a comparative study. Int J Legal Med 2013;127:621-625. DOI: 10.1007/ s00414-013-0841-8

36. Herman-Giddens PA, Smith JB, Mittal M, Butts JD. Newborns killed or left to die by a parent: A population-based study. JAMA 2003;289(11):1425-1429. DOI:10.1001/jama.289.11.1425 